\title{
New approaches in the management of chronic hepatitis B: role of tenofovir
}

\author{
Jurriën GP Reijnders \\ Harry LA Janssen \\ Department of Gastroenterology \\ and Hepatology, Erasmus University \\ Medical Center Rotterdam, The \\ Netherlands
}

\begin{abstract}
In the field of HIV management, tenofovir disoproxil fumarate (TDF) plays a pivotal role and has been demonstrated to be a safe and well-tolerated antiviral agent. Recent data showed the efficacy of TDF in the treatment of chronically hepatitis B virus (HBV)-infected patients. TDF was superior to adefovir dipivoxil (ADV) in both nucleos(t)ide-naïve HBeAg-positive and $\mathrm{HBeAg-negative} \mathrm{HBV} \mathrm{patients,} \mathrm{and} \mathrm{appeared} \mathrm{to} \mathrm{be} \mathrm{one} \mathrm{of} \mathrm{the} \mathrm{most} \mathrm{potent} \mathrm{antiviral} \mathrm{agents} \mathrm{so} \mathrm{far.}$ In addition, several reports showed that TDF was also effective in the nucleos(t)ide-experienced population, although conflicting results have been presented concerning patients with genotypic resistance to ADV. TDF seems to have a good resistance profile as well. The rtA194T mutation in association with lamivudine resistance may confer resistance to TDF, although both in vivo and in vitro studies regarding this mutation demonstrate conflicting results. As treatment with TDF may be associated with nephrotoxicity, all TDF-treated patients should be monitored for renal function at baseline and periodically thereafter. While the relative roles of interferon vs nucleos(t)ide analogues (NA) as initial anti-HBV therapy remains unclear, TDF will probably become one of the key factors in HBV management both as first-choice NA for nucleos(t)idenaïve patients and as rescue therapy for nucleos $(t)$ ide-experienced patients.
\end{abstract}

Keywords: hepatitis B, antiviral therapy, tenofovir, HBV

\section{Introduction}

Although effective vaccines are available, chronic hepatitis B virus (HBV) infection is still a serious global health problem worldwide. Currently, an estimated 350 million people are chronically infected, and 0.5 to 1.2 million subjects die every year due to long-term sequalae of chronic liver disease, such as liver cirrhosis and hepatocellular carcinoma. ${ }^{1,2}$

Hepatitis B has a complex natural history and causes a wide spectrum of disease. A chronic HBV infection is defined by presence of hepatitis B surface antigen (HBsAg) in serum for more than 6 months. The rate of progression from acute to chronic HBV infection is primarily determined by the age at infection, which can be up to $90 \%$ in the setting of perinatal transmission, but is still less than $5 \%$ for adult-acquired HBV infection. ${ }^{3,4}$ Figure 1 depicts the natural course of chronic HBV infection, although it should be recognized that not all patients go through all phases.

In patients with perinatally acquired HBV infection, the immunotolerant phase is the first phase of infection. It is characterized by the presence of hepatitis $\mathrm{B}$ e antigen (HBeAg), a high viral load (>20,000 IU/mL), normal serum aminotransferases, and minimal necroinflammation and fibrosis on liver histology. It may last 1 to 4 decades, 5 but is usually short or absent in patients who acquire HBV infection in their late childhood or during adulthood.

The second phase is the immuno-clearance phase, which is characterized by the presence of HBeAg, high or fluctuating serum HBV DNA levels, persistent or intermittent elevation in serum aminotransferases, and active necroinflammation on liver histology. 
Spontaneous HBeAg seroconversion occurs at a rate of $8 \%$ to $15 \%$ per year. ${ }^{6}$ Frequently, a flare of aminotransferases precedes this important event. ${ }^{7}$ However, most flares only result in transient decreases in serum HBV DNA levels without loss of HBeAg. ${ }^{7}$

The phase that follows HBeAg seroconversion is called the immune-control phase or inactive carrier state. It is characterized by absence of HBeAg, persistently normal aminotransferases, and low serum HBV DNA levels $(<2000 \mathrm{IU} / \mathrm{mL})$. The prognosis is usually benign. After spontaneous $\mathrm{HBeAg}$ seroconversion $67 \%$ of patients will have a sustained remission and low risk of cirrhosis and hepatocellular carcinoma. ${ }^{8,9}$

The fourth phase, chronic HBeAg-negative chronic hepatitis, is characterized by absence of $\mathrm{HBeAg}$, detectable serum HBV DNA levels (>2000 IU/mL), elevated aminotransferases, and active necroinflammation on liver histology. Most patients harbor HBV variants with mutations in the precore or core promoter region, which abolish or downregulate $\mathrm{HBeAg}$ production. ${ }^{10,11}$ Three major patterns can be distinguished in this phase: a recurrent form with exacerbations and periods of remission (45\%), an unremitting form (36\%), and an unremitting form with acute exacerbations $(20 \%){ }^{12}$

\section{Management issues in the treatment of chronic hepatitis B}

Ideally, all patients with chronic HBV infection should be treated; yet currently approved treatment options are unable to eradicate HBV infection. Furthermore, they are expensive, it is unclear whether they are effective in maintaining viral suppression in the light of antiviral drug resistance, and only limited long-term data on safety is available. Therefore, it is suggested to treat only those patients with more active or advanced liver disease, and others most likely to respond. It has generally been accepted that patients with active viral replication (serum HBV DNA > 2000-20,000 IU/mL) and alanine aminotransferase (ALT) levels greater than two times the upper limit of normal (ULN) or advanced fibrosis are candidates for drug therapy, ${ }^{13}$ although it has been argued that strict adherence to these recommendations would exclude a substantial proportion of patients with significant underlying disease from treatment. ${ }^{14-16}$

With the currently approved treatment options the ultimate goal is to prevent the development of long-term sequelae of chronic liver disease. As these clinical outcomes arise only after decades of infection, short-term surrogate endpoints are needed to determine the success of hepatitis B treatment. As a result, permanent and complete suppression of viral replication (at least below 2,000 IU/mL) is the main goal, for persistent HBV viremia is the most important predictor of progression to liver cirrhosis, hepatic failure, and development of hepatocellular carcinoma. ${ }^{17,18} \mathrm{HBeAg}$ seroconversion remains another important endpoint in $\mathrm{HBeAg-}$ positive HBV infection, because it is usually associated with sustained remission and very low risk for development of cirrhosis and hepatocellular carcinoma. ${ }^{8,9}$

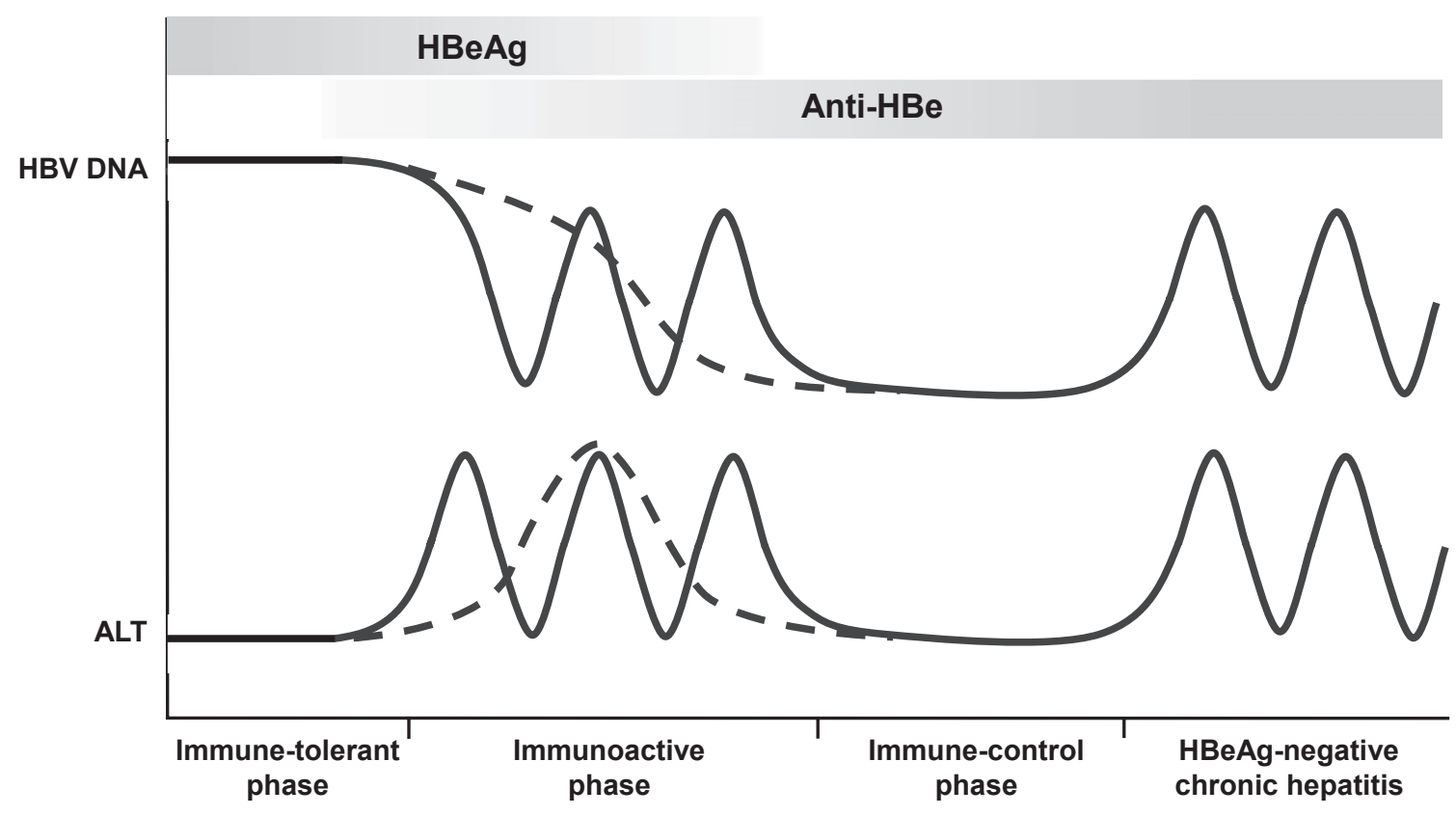

Figure I The natural of history of chronic hepatitis $B$ virus infection.

Abbreviations: $\mathrm{HBV}$, chronic hepatitis $B$ virus; $\mathrm{HBeAg}$, hepatitis $B$ e antigen; $\mathrm{ALT}$, alanine aminotransferase. 


\section{Antiviral therapy}

Currently approved agents include two formulations of interferon (IFN), standard interferon alfa and pegylated interferon (peg-IFN), and five nucleos(t)ide analogues (NA); lamivudine, adefovir, entecavir, telbivudine, and tenofovir. Efficacy, advantages and disadvantages are summarized in Table 1. ${ }^{19-30}$ Although available randomized controlled trials show encouraging short-term results, demonstrating the favorable effect of these agents on intermediate end points as HBV DNA level, liver enzyme tests and liver histology, limited rigorous evidence exists demonstrating the effect of these therapies on important long-term clinical outcomes such as the development of hepatocellular carcinoma or a reduction in liver-related deaths. ${ }^{31}$

\section{Interferon therapy}

IFN alfa has been used since the early 1990s for the treatment of chronic HBV infection. It largely acts through enhancement of the immunological response of the host against the virus, although there is also limited direct antiviral effect on HBV replication. ${ }^{32}$ This immunomodulatory mode of action is reflected in higher rates of $\mathrm{HBeAg}$ and $\mathrm{HBsAg}$ seroconversion, and a more durable response once treatment is discontinued (sustained response) compared to treatment with NA. ${ }^{23,27,30,33}$ Pegylation of IFN led to improved pharmacokinetic and pharmacodynamic properties, and resulted in a slightly increased efficacy and more convenience compared to standard IFN. ${ }^{34}$ Among HBeAg-positive patients, subjects with HBV genotype A tend to respond much better than subjects with genotype non-A. ${ }^{23}$ Follow-up studies demonstrated that IFN had long-term benefits in that it promotes cumulative $\mathrm{HBeAg}$ and HBsAg seroconversion, prevention of cirrhosis and hepatocellular carcinoma, and prolonged survival. ${ }^{35,36}$ However, IFN-based therapy is associated with a wide spectrum of adverse events, including flu-like symptoms, emotional lability, and bone marrow depression. Still, only few patients require dose modification or discontinuation of treatment, and symptomatic therapy fulfils in most instances. ${ }^{34}$ IFN is contraindicated in patients with decompensated liver cirrhosis, but has proven to be safe and effective in patients with advanced fibrosis and compensated liver disease. ${ }^{37}$

\section{Nucleos(t)ide analogue therapy}

The introduction of NA heralded a new era in the treatment of chronic hepatitis B, and provided a safe, effective, and welltolerated alternative for IFN. NA target the reverse transcriptase of $\mathrm{HBV}$ and are potent inhibitors of viral replication. Initiation of treatment usually results in a rapid decline of serum HBV
DNA levels. Nevertheless, this antiviral potency does not result in increased $\mathrm{HBeAg}$ seroconversion rates ( $\sim 20 \%$ after 1 year of therapy), and HBsAg-seroconversion is very rare (Table 1).

A major drawback is that NA probably have to be administered for extremely long periods of time, if not indefinitely. HBV covalently closed circular DNA (cccDNA) plays a major role in viral persistence. ${ }^{38}$ Yet, it is questionable whether NA are, in fact, able to deplete the pool of intrahepatic cccDNA to levels below which the immune response might be able to control the infection. First, none of the currently available NA has demonstrated to be able to prevent de novo formation of cccDNA in infected hepatocytes. New hepatocytes will, therefore, continue to be infected as long as residual circulating virions are present in the bloodstream. Second, incomplete inhibition of viral synthesis allows recycling of nucleocapsids towards the nucleus thereby maintaining the cccDNA pool. ${ }^{38,39}$ It has been shown that adefovir (ADV) monotherapy is able to decrease intrahepatic cccDNA. ${ }^{40}$ Yet, based on these data mathematical models predicted that it would take at least 14 years to completely clear a chronically infected liver of intracellular cccDNA. ${ }^{41}$ Furthermore, when ADV was combined with peg-IFN, clearance of cccDNA was enhanced, and in contrast to ADV monotherapy, it also resulted in a strong reduction of HBV antigen-positive hepatocytes. ${ }^{42}$ Together with the increased $\mathrm{HBeAg}$ and $\mathrm{HBsAg}$ seroconversion rates with peg-IFN monotherapy, these findings indicate that to eradicate HBV, modulation of the immune response, whether or not induced by peg-IFN, is of vital importance. In conclusion, with NA therapy suppression of viral replication can be maintained over prolonged periods with ongoing therapy (maintained response), but a sustained off-treatment response seems only possible in a minority of patients. Current guidelines recommend that, in $\mathrm{HBeAg}$-positive patients, treatment may be stopped after $\mathrm{HBeAg}$ seroconversion and at least 6 months of consolidation therapy. In HBeAg-negative patients, discontinuation is only possible after HBsAg loss. ${ }^{13}$

Long-term treatment is associated with an increased risk for development of antiviral drug resistance, which can eventually lead to reversion of virologic and histological improvement, and enhance the rate of disease progression. ${ }^{43}$ Antiviral drug resistance reflects reduced susceptibility of a virus to the inhibitory effect of a drug. It results from a process of adaptive mutations under therapy. The first manifestation of antiviral resistance is a virologic breakthrough which is defined as a $>1 \log _{10}$ increase in serum HBV DNA from nadir during treatment in a patient who had an initial virologic response. It is usually also followed by a biochemical breakthrough. HBV has a high rate of replication, with $10^{12}$ virions produced per day and a high 
Table I One year efficacy, advantages, and disadvantages of approved treatments of chronic hepatitis B

\begin{tabular}{|c|c|c|c|c|c|c|c|c|c|c|c|c|}
\hline & \multicolumn{2}{|c|}{ Peg-IFN } & \multicolumn{2}{|c|}{ Lamivudine } & \multicolumn{2}{|l|}{ Adefovir } & \multicolumn{2}{|c|}{ Entecavir } & \multicolumn{2}{|c|}{ Telbivudine } & \multicolumn{2}{|c|}{ Tenofovir } \\
\hline & $\mathbf{e}(+)$ & $\mathbf{e}(-)$ & $\mathbf{e}(+)$ & e(-) & $\mathbf{e}(+)$ & $\mathbf{e}(-)$ & $\mathbf{e}(+)$ & $e(-)$ & $\mathbf{e}(+)$ & $\mathbf{e}(-)$ & $\mathbf{e}(+)$ & $\mathbf{e}(-)$ \\
\hline Dose/route & \multicolumn{2}{|c|}{ subcutaneous } & \multicolumn{2}{|l|}{ oral } & \multicolumn{2}{|l|}{ oral } & \multicolumn{2}{|l|}{ oral } & \multicolumn{2}{|l|}{ oral } & \multicolumn{2}{|l|}{ oral } \\
\hline \multicolumn{13}{|l|}{ HBV DNA } \\
\hline Log reduction & 2.4 & 2.3 & $5.4-5.8$ & $4.2-4.5$ & 3.6 & 3.7 & 6.9 & 5.0 & 6.5 & 5.2 & NA & NA \\
\hline Undetectable ${ }^{\mathrm{a}}$ & $14 \%$ & $19 \%$ & $40 \%$ & $73 \%$ & $12 \%-21 \%$ & $51 \%-59 \%$ & $67 \%$ & $90 \%$ & $60 \%$ & $88 \%$ & $74 \%$ & $92 \%$ \\
\hline $\mathrm{HBeAg}$ seroconversion & $32 \%$ & NP & $18 \%-22 \%$ & NP & $12 \%-18 \%$ & NP & $21 \%$ & NP & $23 \%$ & NP & $21 \%$ & NP \\
\hline $\mathrm{HBs} A g$ seroconversion & $3.0 \%$ & $2.8 \%$ & $0 \%$ & $0 \%$ & $0 \%$ & $0 \%$ & $0 \%$ & $0 \%$ & $0 \%$ & $0 \%$ & $0 \%$ & $0 \%$ \\
\hline ALT normalization & $41 \%$ & $59 \%$ & $60 \%-75 \%$ & $73 \%-79 \%$ & $48 \%-54 \%$ & $72 \%-78 \%$ & $68 \%$ & $78 \%$ & $77 \%$ & $74 \%$ & $69 \%$ & $77 \%$ \\
\hline Side effects & \multicolumn{2}{|c|}{ Many } & \multicolumn{2}{|c|}{ Negligible } & \multicolumn{2}{|c|}{ Nephrotoxicity } & \multicolumn{2}{|c|}{ Negligible } & \multicolumn{2}{|c|}{ Negligible } & \multicolumn{2}{|c|}{ Nephrotoxicity } \\
\hline \multicolumn{13}{|l|}{ Drug resistance } \\
\hline Year I & \multicolumn{2}{|c|}{ NA } & \multicolumn{2}{|c|}{$24 \%$} & \multicolumn{2}{|c|}{$0 \%$} & \multicolumn{2}{|c|}{$0.1 \%$} & \multicolumn{2}{|c|}{$6.8 \%$} & \multicolumn{2}{|c|}{$0 \%$} \\
\hline Year 2 & \multicolumn{2}{|c|}{ NA } & \multicolumn{2}{|c|}{$42 \%$} & \multicolumn{2}{|c|}{$3 \%$} & \multicolumn{2}{|c|}{$0.3 \%$} & \multicolumn{2}{|c|}{$17 \%$} & \multicolumn{2}{|c|}{$0 \%$} \\
\hline Year 3 & \multicolumn{2}{|c|}{ NA } & \multicolumn{2}{|c|}{$53 \%$} & \multicolumn{2}{|c|}{$11 \%$} & & $4 \%$ & & & $\mathrm{~N}$ & \\
\hline Year 4 & & A & & $\%$ & & & & $8 \%$ & & & $\mathrm{~N}$ & \\
\hline Year 5 & & A & & $\%$ & & & & $2 \%$ & & & $\mathrm{~N}$ & \\
\hline
\end{tabular}

a Undetectable HBV DNA is defined as less than 400 copies $/ \mathrm{mL}$. Studies on entecavir and telbivudine used $300 \mathrm{copies} / \mathrm{mL}$.

Abbreviations: ALT, alanine aminotransferase; HBV, hepatitis B virus; $\mathrm{HBs} A$ g, hepatitis B surface antigen; $\mathrm{HBeAg}$, hepatitis B e antigen; NA, not applicable; NP, not possible; Peg-IFN, pegylated interferon.

mutational rate of approximately $10^{-5}$ substitutions/base/cycle. ${ }^{44}$ This translates to approximately $10^{10-11}$ point mutations per day in individuals with active viral replication. For the HBV reverse transcriptase does not have a proofreading mechanism, mutations can arise very quickly. As a consequence, a diversity of viruses (quasispecies), including mutants with single and double mutations potentially associated with drug resistance, may exist prior to therapy. Furthermore, development and amplification of mutant populations is replication-dependent, meaning that resistance only emerges when replication occurs in the presence of the drug selection pressure. Several studies have already shown that an initial virologic response is associated with lower rates of antiviral drug resistance in HBV patients in the long term. ${ }^{25,45,46}$ Therefore, antiviral therapy, once initiated, should aim to suppress viral replication as quickly and completely as possible. To prevent the emergence of antiviral drug resistance only potent NA with a high genetic barrier, meaning drugs requiring multiple resistance mutations, should be used as monotherapy.

It is currently recommended to start with monotherapy and to use an add-on strategy in case of development of resistant HBV mutants. ${ }^{13}$ However, treatment strategies focused on preventing development of resistance by suppressing viral replication as quickly and completely as possible, have also been advocated. The so-called roadmap concept, which concerns on-treatment monitoring during NA treatment, was recently proposed ${ }^{47}$ In order to prevent future development of antiviral drug resistance, virologic response should be assessed at week 12 and 24 to identify suboptimal response and to modify treatment accordingly. However, it is questionable whether this concept still applies if potent drugs with low resistance rates are used from the start. Another option is to offer de novo combination of NA therapy. The concept of combination therapy has long been established as the paradigm of therapy for a number of other chronic infections. In the treatment of HIV, it has not only been proven to diminish or delay the occurrence of resistance due to greater potency and a higher genetic barrier, but also to reduce mortality. ${ }^{48}$ Nevertheless, in the light of antiviral agents with excellent resistance profiles, the benefit of de novo combination therapy may be difficult to demonstrate in HBV-monoinfected patients.

\section{Pharmacological properties and mode of action of tenofovir}

Tenofovir [9-(R)-(2-phosphonomethoxypropyl)adenine, PMPA] belongs to a class of acyclic phosphanate nucleotide analogues. Its antiviral activity was first described in 1993, and, in contrast to adefovir, the antiviral activity spectrum of tenofovir is restricted to retroviruses and hepadnaviruses, and does not encompass herpesviruses. ${ }^{49}$ To increase bioavailability by the oral route, tenofovir has been converted to its oral prodrug form, tenofovir disoproxil, by adding two alkyl methyl carbonate esters. ${ }^{50}$ Due to improved cellular permeability in vitro studies demonstrated a 50 -fold increase in potency. ${ }^{51}$ 
Upon oral administration, tenofovir disoproxil fumarate (TDF) is rapidly hydrolyzed after gastrointestinal absorption, which removes the two ester groups after which the free parent compound is released into the circulation. ${ }^{50,52}$ Tenofovir is taken up by cells via a passive process endocytosis, then phosphorylated by the cellular nucleotide kinase, adenylate kinase, to the monophosphate intermediate and then rapidly converted by nucleoside diphosphate kinase to the active diphosphate form. ${ }^{53}$ Tenofovir diphosphate selectively inhibits the reverse transcriptase- DNA polymerase of HBV through competition with the natural substrate deoxyadenosine 5 '-triphosphate for incorporation into DNA during HBV transcription. As tenofovir lacks a 3'-hydroxyl group, incorporation in DNA prevents further DNA chain elongation, and causes termination of viral DNA growth. ${ }^{54}$ Tenofovir is primarily eliminated through the kidney. It is cleared by a combination of glomerular filtration and active secretion by the proximal tubular cells. ${ }^{55}$

\section{Pharmacokinetics and pharmacodynamics}

Dose-escalating pharmacokinetic studies have only been performed in HIV-infected patients. Following 28 days of dosing, administration of TDF once daily at all of the doses studied $(75,150,300,600 \mathrm{mg})$ resulted in significant decreases in serum HIV-1 RNA levels, with the greatest effect achieved at the 300-mg dose, despite dose-proportional increases in drug exposure. ${ }^{56}$ In addition, the efficient phosphorylation and long intracellular half-life of tenofovir diphosphate ( $\geq 60$ hours) indicates that a single daily dose of TDF is sufficient to exert a potent antiviral effect in the liver, which is supported by the results of clinical pharmacokinetic studies. ${ }^{51}$ Furthermore, TDF can be administered without regard to meals, and no demographic parameters affect tenofovir pharmacokinetics across patients or healthy subjects. ${ }^{55}$ As TDF is primarily cleared through the kidney, dosage adjustments are required in patients with moderate and severe renal impairment and in those end-stage renal disease patients maintained on long-term hemodialysis (Table 3). ${ }^{55}$ No substantial alterations were observed in patients with moderate or severe hepatic impairment. ${ }^{55} \mathrm{TDF}$ is not approved for use in children younger than 18 years of age. Until now, only one small uncontrolled study of safety and pharmacokinetics has been performed in children, demonstrating similar results as seen in adult patients. ${ }^{57}$ Tenofovir is not a substrate, inducer or inhibitor of human cytochrome $\mathrm{P} 450$ enzymes, which suggests a low potential for clinically important drug-drug interactions with drugs that are substrates or inducers/inhibitors of these enzymes.
Multiple clinical drug-interaction studies have been done with mainly medications that are frequently prescribed in HIV-1-infected subjects. With the exception of didanosine and atazanavir, which both require dose modifications; no clinically significant drug interactions have been observed with TDF. ${ }^{55}$

\section{Clinical efficacy of tenofovir disoproxil fumarate Efficacy of TDF in patients with a HIV/HBV coinfection}

TDF was licensed for the treatment of human immunodeficiency virus (HIV) infection in 2001, and plays since then a pivotal role in HIV management. Currently, the combination of TDF and emtricitabine is the most widely prescribed nucleos(t)ide reverse transcriptase inhibitor (NRTI) backbone in Europe, and is being used in many clinical trials. Because HIV and HBV share similar routes of transmission, prevalence of HBsAg-carriership is more than 5-fold higher among HIV-infected patients compared to the general population. ${ }^{58,59}$ As a logical consequence, the efficacy of TDF in HBV therapy was first described in several small studies including mainly patients with HIV-1 co-infection, and some receiving combination therapy with lamivudine (LAM) ${ }^{60-78}$ In 2002 the clinical anti-HBV efficacy of TDF was first reported by Nunez et al who described $12 \mathrm{HBV} / \mathrm{HIV}$ coinfected patients with detectable HBV DNA levels, despite receiving a LAMcontaining antiretroviral regimen. After the addition of TDF a drop in viral load of $3.78 \log _{10}$ copies/mL after 24 weeks of treatment was observed. ${ }^{71}$ Larger studies confirmed these early observations. Van Bommel et al compared the antiviral efficacy of TDF with ADV in a mixed population of $\mathrm{HBV}$ monoinfected and HBV/HIV coinfected patients with genotypic evidence of LAM-resistance $(n=53)$. After 48 weeks of treatment all TDF-treated subjects achieved undetectable HBV DNA levels (<400 copies/mL), whereas this endpoint by only $44 \%$ of ADV-treated patients was demonstrated. Moreover, HBeAg loss occurred in 11 (35\%) of $31 \mathrm{HBeAg}-$ positive patients, and HBsAg loss was observed in $5(14 \%)$ of TDF-treated patients during the study period (72-130 weeks). ${ }^{77}$ A recently performed randomized controlled trial confirmed that TDF is clearly not inferior to ADV, and thus demonstrated that a TDF-containing antiretroviral regimen is preferable for HIV/HBV coinfected patients, when treatment for HIV infection is indicated. The conclusion that TDF is superior to ADV based on this study should however be made with caution, as it was designed and powered to demonstrate 
non-inferiority. ${ }^{72}$ Benhamou et al presented a retrospective analysis of $65 \mathrm{HIV} / \mathrm{HBV}$ coinfected patients with detectable HBV DNA ( $>200$ copies/mL) at the start of TDF therapy. Most patients (95\%) had previously received LAM and developed mutations conferring LAM-resistance (69\%). In 52 patients who were on LAM at the initiation of TDF, LAM therapy was maintained throughout the study. During median treatment duration of 12 months HBV DNA levels became undetectable in $30 \%$ and $82 \%$ of HBeAg-positive and $\mathrm{HBeAg-negative} \mathrm{patients,} \mathrm{respectively.} \mathrm{Four} \mathrm{(7 \% )} \mathrm{of}$ $54 \mathrm{HBeAg}$-positive patients showed HBeAg loss, but HBsAg loss was observed in none of the patients. ${ }^{61}$ In a recent randomized clinical trial $36 \mathrm{HIV} / \mathrm{HBV}$ coinfected subjects initiating highly active antiretroviral therapy (HAART) were randomized to either LAM, TDF, or LAM-TDF as HBV-active drugs within HAART. After 48 weeks of treatment a TDF-containing treatment regimen resulted in a greater proportion of subjects with a viral load less than 1000 copies/mL (46\% vs 92\% vs $91 \%$; $\mathrm{p}=0.013$ ). HBeAg and HBsAg loss was observed in $31 \%$ and $9 \%$ of TDF-treated patients, respectively. No differences in response were seen between patients treated with TDF and patients treated with TDF/LAM in this short-term setting. ${ }^{68}$

\section{Efficacy of TDF in patients with chronic HBV monoinfection}

The results of two international phase III clinical trials, in which the efficacy of TDF is compared with ADV, have recently been presented (Figure 2). ${ }^{22,28}$ One study studied
HBeAg-positive nucleos(t)ide-naïve patients, the second at HBeAg-negative nucleos(t)ide-naïve patients. Both trials used a 2:1 randomization for patients to receive either TDF $300 \mathrm{mg} /$ day or ADV $10 \mathrm{mg} /$ day. Primary efficacy was evaluated at 48 weeks. The primary endpoint was the combined presence of HBV DNA levels below 400 copies $/ \mathrm{mL}$ and histological improvement, defined as a $\geq 2$-point reduction in Knodell necroinflammatory score without worsening fibrosis. After 48 weeks all eligible subjects with a week 48 biopsy were switched to open-label TDF monotherapy for up to an additional 8 years.

In the HBeAg-positive nucleos(t)ide-naïve study, 266 patients with compensated liver disease were 2:1 randomized to receive either TDF $300 \mathrm{mg} /$ day or $\mathrm{ADV}$ $10 \mathrm{mg} /$ day. $^{22}$ At the end of 48 weeks of treatment $67 \%$ of the TDF-treated patients achieved the primary endpoint versus only $12 \%$ of ADV-treated patients $(p<0.001)$ (Table 2 ). A total of $76 \%$ of TDF-treated patients demonstrated undetectable HBV DNA ( $<400$ copies/mL) compared to $13 \%$ of $A D V$-treated subjects $(\mathrm{p}<0.001$ ). In addition, more patients in the TDF-treated group had normalization of ALT than in the ADV-treated groups (69\% vs 54\%; $\mathrm{p}=0.02$ ). $\mathrm{HBeAg}$ seroconversion was similar in the two treatment arms (21\% vs 18\%), but HBsAg loss occurred significantly more in the TDF-treated group (3.2\% vs $0 \% ; \mathrm{p}=0.02)$. After week 48 , $154(88 \%)$ of 176 TDF-treated patients continued therapy, which produced additional viral suppression, and HBeAg and HBsAg loss at week 72 and 96. ${ }^{79,80}$ Eighty-four (93\%) subjects

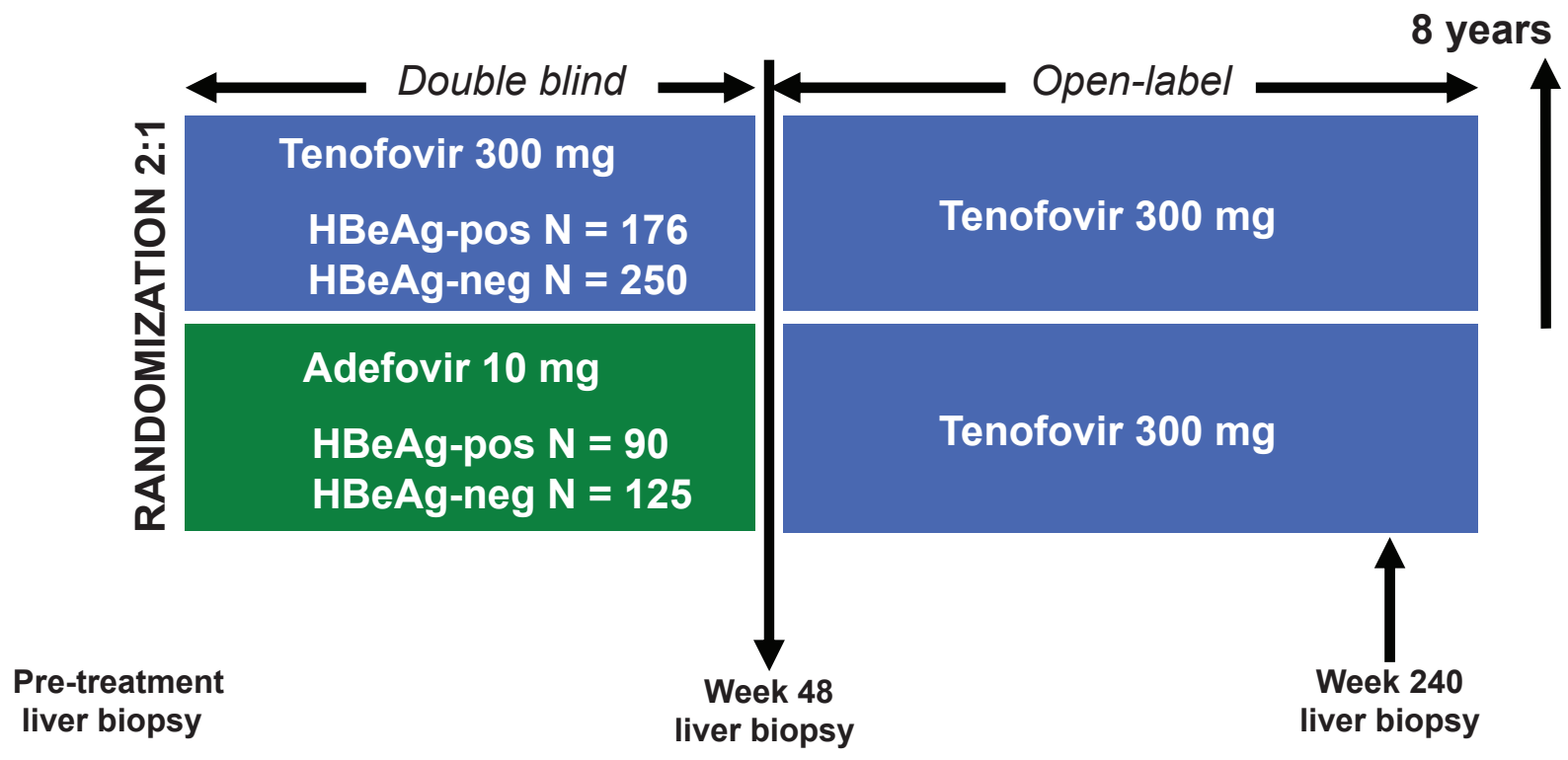

Figure 2 Study design of two randomized trials comparing the efficacy of tenofovir to adefovir in both $\mathrm{HBeAg-positive} \mathrm{and} \mathrm{HBeAg}$-negative chronic hepatitis B patients. At or after week 72 there is an option to initiate emtricitabine-tenofovir combination therapy for confirmed HBV DNA $>400$ copies $/ \mathrm{mL}$. Current follow-up is up to 96 weeks of treatment. Abbreviations: $\mathrm{HBeAg}$, hepatitis $\mathrm{B}$ e antigen. 
originally randomized to ADV initiated TDF at week 48, of whom 72 patients demonstrated HBV DNA still greater than 400 copies/mL. By week 72, patients switched from ADV to TDF monotherapy showed similar rates of undetectable HBV DNA as those receiving continous TDF monotherapy (intention-to-treat [ITT] analysis: $79 \%$ vs $76 \%$; $=0.62$ ). ${ }^{80} \mathrm{At}$ week 96, all 12 patients suppressed on ADV remained suppressed on TDF, and $82 \%$ of the other 72 patients achieved undetectable HBV DNA. From the total study population, a total of 28 patients switched to open-label emtricitabine (FTC)-TDF combination therapy due to persistent HBV DNA levels greater than 400 copies $/ \mathrm{mL}^{79}$

In the HBeAg-negative, nucleos(t)ide-naïve study, 375 patients were randomized to receive TDF $300 \mathrm{mg} /$ day $(\mathrm{n}=250)$ or ADV $10 \mathrm{mg} /$ day $(\mathrm{n}=125) .{ }^{28}$ After 48 weeks of treatment $71 \%$ of TDF-treated patients achieved the primary endpoint and 93\% demonstrated HBV DNA lower than 400 copies/mL. Within the ADV-treated group, only $49 \%$ and $63 \%$ of patients achieved these endpoints, respectively $(\mathrm{p}<0.001)$ (Table 2). No significant differences were observed between the two treatment groups concerning histological improvement (72\% vs 69\%) and ALT normalization (77\% vs 77\%). HBsAg loss was not observed in either group. After week 48, 235 (94\%) of 250 TDF-treated patients continued treatment, which resulted in increased viral suppression at week 72 and $96 .{ }^{81,82}$ One hundred and twelve (90\%) subjects who initially were treated with ADV switched to TDF monotherapy at week 48 . Within this group, 35 patients had HBV DNA greater than 400 copies/mL just prior to switching to TDF. At week 72, 108 of 112 subjects demonstrated undetectable HBV DNA, and at week 96 all patients who were on study showed HBV DNA below 400 copies/mL (ITT analysis week 96: 89\%). None of the patients switched to open-label FTC-TDF combination therapy. ${ }^{81,82}$

\section{Efficacy of TDF in nucleos(t)ide-experienced patients with chronic HBV infection}

\section{Lamivudine}

LAM was the first nucleoside analogue to be approved for the treatment of chronic HBV infection, and remained the only available oral anti-HBV agent for several years. A major limitation is, however, its inferior resistance profile, which leads to a resistance rate of approximately $20 \%$ of patients per year. ${ }^{83}$ As a result, LAM is no longer considered as a first-line agent for patients with a chronic HBV monoinfection. LAM also demonstrates significant anti-HIV activity, and is commonly used as part of an anti-HIV combination treatment regimen. Therefore, in most case series of TDF-treated HIV/HBV coinfected patients, subjects were LAM-experienced to a large extent, and often received TDF as rescue therapy after development of LAM-resistance. As mentioned above, TDF demonstrated within this patient group profound antiHBV activity. In a recent study, the long-term efficacy and safety of TDF monotherapy in treatment-experienced patients with chronic HBV mono-infection was described. Patients with genotypic resistance to ADV at baseline were excluded. Of 108 patients, 93 (86\%) subjects were LAMexperienced, and in $60 \%$ of patients mutations associated with resistance to LAM could be detected at the beginning of TDF treatment. In their analysis, both preceding treatment with LAM and the presence of LAM resistance did not affect the response to TDF monotherapy. ${ }^{84}$ These findings were confirmed by Manns et al who performed a posthoc analysis of pooled data from two randomized trials of TDF in HBeAg-positive and $\mathrm{HBeAg-negative} \mathrm{HBV}$ patients. In this study, 49 patients were LAM-experienced, which was defined as prior treatment with LAM for at least 12 weeks. In 10 patients LAM-resistant mutations were detected at baseline. After 48 weeks of TDF treatment response rates between LAM-experienced and LAM-naïve patients were comparable (HBV DNA $<400$ copies/mL: $88 \%$ vs $86 \%) .{ }^{85}$

\section{Adefovir (ADV)}

ADV is a nucleotide analogue similar in structure to TDF, and was the second oral agent approved for the treatment of chronic HBV infection. As nephrotoxicity is a major side effect of higher doses, the prescribed dose is approximately 30-fold lower than TDF, and probably accounts for its low potency in vivo. ${ }^{21,29}$ The higher potency of TDF is shown in 3 case series in which replacement of TDF with ADV resulted in the reappearance of viral replication. ${ }^{86-88}$ Furthermore, another study demonstrated in 20 lamivudine-refractory HBV-infected patients with a suboptimal response to ADV that switching to TDF resulted in further viral suppression. In a median time of 3.5 months 19 of 20 patients achieved undetectable HBV DNA levels ( $<400$ copies/mL), and a median $3.8 \log _{10}$ reduction of HBV DNA was demonstrated after 12 months of treatment. In addition, 4 patients lost $\mathrm{HBeAg}$ and 1 patient additionally seroconverted from $\mathrm{HBsAg}$ to anti-HBs. ${ }^{89}$ These findings were confirmed by two randomized trials, in which all eligible patients randomized to 48 weeks of ADV monotherapy were switched to open-label TDF monotherapy at week 48 (Table 2). ${ }^{79-82}$ Van Bommel et al showed in a retrospective analysis of a cohort of mainly treatment-experienced patients that subjects with genotypic 


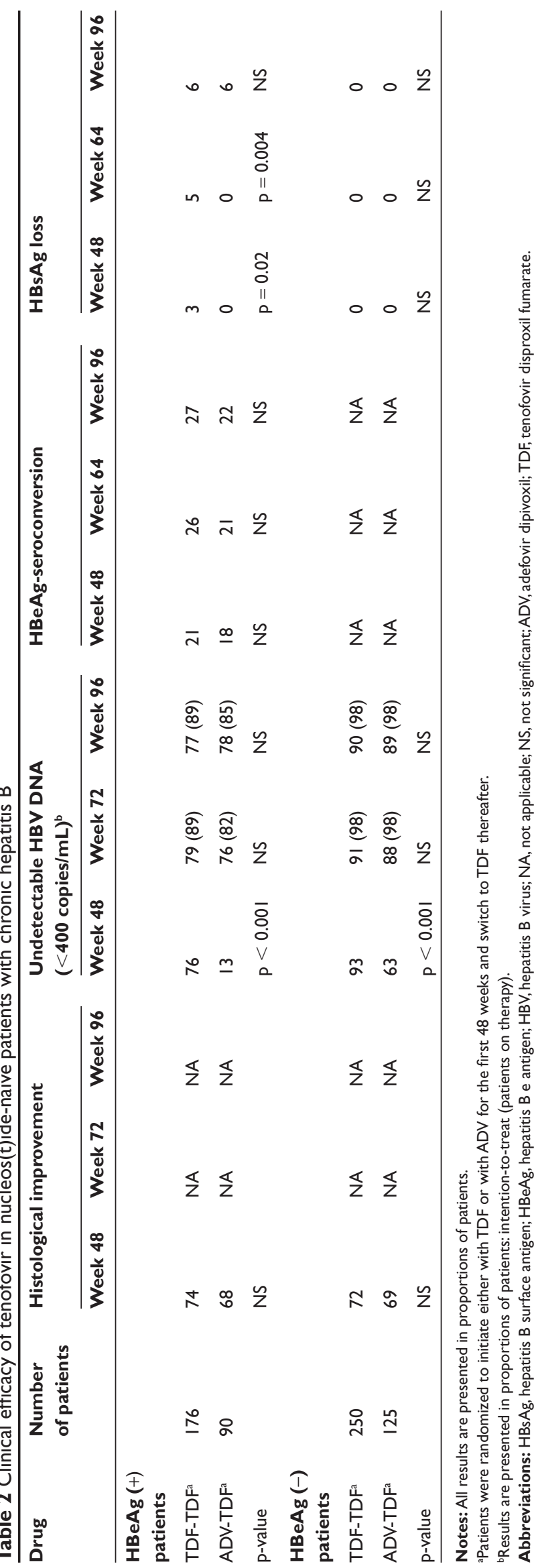

ADV resistance at the initiation of TDF had significantly slower decrease of HBV DNA after 12 months of treatment. Nevertheless, during the total observation period all patients with a viral load at baseline of less than $7 \log _{10}$ copies $/ \mathrm{mL}$ achieved undetectable HBV DNA $(<400$ copies $/ \mathrm{mL}) .{ }^{90} \mathrm{In}$ 2 patients with high baseline viremia $\left(>7 \log _{10}\right.$ copies $/ \mathrm{mL}$ ) this endpoint was only achieved after addition of LAM. ${ }^{91}$ Similar to these results, another study showed that TDF monotherapy might only be effective in patients with antiviral treatment failure to ADV in the absence of ADV-resistant mutations. ${ }^{92}$ Moreover, it is interesting that in both studies HBV mutants harboring ADV-resistant mutations persisted during TDF monotherapy, which may imply a selective advantage for these HBV variants. ${ }^{91,92}$ However, TDF has been used successfully for the treatment of patients who failed consecutive therapy with lamivudine and lamivudine-adefovir combination. ${ }^{93}$ Furthermore, similar results were reported in a randomized clinical trial, in which the efficacy of TDF monotherapy is compared to TDF/FTC combination therapy in patients with persistent viremia during ADV monotherapy. At week 48 viral replication was suppressed to levels below 400 copies $/ \mathrm{mL}$ in $81 \%$ of patients in both treatment arms. In addition, TDF monotherapy resulted in undetectable HBV DNA in 7 of 8 patients with genotypic resistance to ADV at baseline. ${ }^{94}$

\section{Entecavir}

Entecavir (ETV) has a high potency and is associated with minimal resistance in the long-term treatment of nucleos(t)ide-naïve HBV-infected patients, which both underscore the position of ETV for first-line therapy. ${ }^{19,26}$ However, its efficacy is compromised by prior development of LAM-resistance, and ETV may thus not be the best rescue option for LAM-experienced patients. ${ }^{95}$ Experience with TDF in patients previously treated with ETV is limited. A recent case report shows TDF to be effective in a patient who experienced a virologic breakthrough after development of resistance to ETV ${ }^{96}$ Furthermore, in 7 patients with a suboptimal virologic response without the presence of ETV-resistant mutations, switching to TDF monotherapy resulted in a rapid decline of viral load. ${ }^{97}$

\section{Efficacy of TDF in cirrhotic patients with chronic HBV infection}

A study within seven cirrhotic patients with a HIV/HBV coinfection demonstrated that treatment with TDF led to profound suppression of viral replication, and even was able to significantly improve markers of hepatic function. All 3 patients 
with decompensated liver disease recompensated, which for 1 subject enabled removal from the liver transplant waiting list. ${ }^{69}$ In a posthoc analysis of pooled data from 2 randomized trials in $\mathrm{HBeAg}$-positive and $\mathrm{HBeAg}$-negative $\mathrm{HBV}$ patients, TDF produced consistent responses among cirrhotic and noncirrhotic patients after 48 weeks of treatment. ${ }^{98}$

\section{Resistance profile of TDF}

Until now TDF resistance has only been described in 2 HIV-HBV co-infected patients demonstrating the A194T mutation in addition to LAM-resistance. ${ }^{99}$ This study investigated $43 \mathrm{HIV} / \mathrm{HBV}$ coinfected patients who had persistently detectable HBV DNA despite $\geq 24$ weeks of TDF/LAM combination treatment. The rtA194T mutation was detected 48 and 77 weeks after initiation of TDF. In one patient a HBV subpopulation with mutations rtM204V, rtL180M, and rtA194T could be detected. This coincided with a hepatitis flare, although it should be noted that there was also an increase of his CD4+ T cell count. Nevertheless, HBV DNA increased from 2.6 to $4.1 \log _{10}$ copies/mL as well, and remained at that level thereafter. The other patient presented with mutations in the HBV polymerase of rtM204V, rtL180M, rtV173L, and rtA194T, but there was a progressive decline in both HBV DNA and alanine aminotransferase (ALT) levels. Another study reported of $5 \mathrm{HBV}$-infected patients also harboring the rtA194T mutation in association with LAM-resistance. ${ }^{100}$ A TDF-containing salvage treatment regimen was started after antiviral treatment failure to LAM. All patients demonstrated a rapid decline in viral load, and 4 of these achieved HBV DNA levels below $6 \mathrm{IU} / \mathrm{mL}$. In vitro studies show that the rtA194T mutation alone resulted in a 7.6-fold decrease in susceptibility, but in conjunction with rtM204V and rtL180M led to a more than 10-fold decrease in susceptibility to TDF. ${ }^{99}$ These mutations also negatively impacted replication competence of the HBV mutants. It was, however, demonstrated that viral replication could be restored to wild-type levels if these occurred together with precore or basic core promoter substitutions, as for a patient

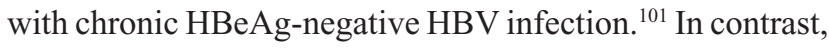
in a study by Delaney et al the rtA194T mutation, whether or not in combination with LAM-resistant mutations, did not confer resistance to TDF in vitro. ${ }^{51}$

As mentioned above, clinical studies regarding the efficacy of TDF in HBV patients with genotypic ADV resistance demonstrate conflicting results. ${ }^{91-94}$ In vitro studies, however, show that both rtN236T and rtA181V/T HBV mutants remain sensitive to TDF, and are only associated with small decreases in susceptibility..$^{51,93,102-105}$ In addition,
Table 3 Recommendations for administration of tenofovir disiproxil fumarate $300 \mathrm{mg}$ to patients with renal impairment

\begin{tabular}{ll}
\hline Clinical condition & Administration interval \\
\hline CLcr $(\mathrm{mL} / \mathrm{min})^{\mathrm{a}}$ & \\
$>50$ & Every $24 \mathrm{~h}$ \\
$30-49$ & Every $48 \mathrm{~h}$ \\
$10-29$ & Twice weekly \\
ESRD requiring hemodialysis & Every 7 days or after a total \\
& of approximately \\
& $12 \mathrm{~h}$ of dialysis \\
\hline
\end{tabular}

${ }^{a}$ Creatinine clearance.

Abbreviation: ESRD, end stage renal disease.

observed susceptibility shifts are smaller than for ADV, and together with the significantly higher dose, TDF should be able to effectively suppress viral replication in patients with genotypic ADV resistance. These studies also demonstrated that LAM-resistant HBV mutants remain completely sensitive to TDF.

In the two phase III clinical trials, direct sequencing was performed at baseline, and at week 48 and 96 in all TDF-treated patients with a viral load above 400 copies/mL. ${ }^{106,107}$ Phenotypic analysis was done in those subjects harboring conserved site changes and those experiencing virologic breakthrough. Ten patients showed a virologic breakthrough in the first year of treatment; in 5 patients it was observed during the second year. Yet, the majority of these subjects had evidence of non-adherence. Furthermore, none of them developed conserved site changes. Overall, the occurrence of conserved site changes was rare. Despite this extensive resistance surveillance, no evidence of TDF-resistance was shown so far in both nucleos(t)ide-naïve and experienced patients. In addition, no naturally occurring baseline polymorphisms were associated with a reduced virologic response to TDF.

\section{Safety and tolerability}

Recently, TDF achieved the milestone of 1.5 million patientyears of experience. As TDF is one of the most widely prescribed antiretroviral agents, information on the safety profile of TDF mainly comes from its use in HIV-infected subjects. TDF is generally well tolerated with only few side effects. There have been concerns about the risk of renal toxicity with TDF due to an association between related compounds such as ADV and nephrotoxicity. A recent study demonstrated that the 4-year cumulative rates of renal impairment and arterial hypertension was $18 \%$ for both within a large cohort of 271 chronic hepatitis B patients treated with LAM-ADV combination treatment. ${ }^{108}$ Data on the risk of nephrotoxicity with TDF are, however, somewhat inconsistent. Several case 
reports have described renal toxicity in HIV-infected persons receiving TDF, including renal failure and Fanconi's syndrome. ${ }^{109-111}$ Within a large cohort declines in creatinine clearance were observed, that were significantly greater in patients receiving a TDF-containing regimen. Yet, changes were only small, and did not lead to a higher discontinuation rate. ${ }^{12}$ The clinical relevance is therefore questionable. In another cohort, TDF was not associated with renal dysfunction more frequently than with other anti-HIV agents, and in most cases exposed to TDF, it could even be attributed to other causes. ${ }^{113}$ In the Tenofovir Expanded Access programme, which was initiated prior to commercial availability in 2001, serious renal events were reported in $0.5 \%$ of 10,343 patients. The percentage experiencing any graded serum creatinine abnormality was $2.2 \%$. A multivariate analysis demonstrated that elevated serum creatinine at the initiation of TDF, concomitant nephrotoxic medication, and older age were important risk factors. The most common serious renal abnormalities observed in this population, and in the postmarketing safety database, were renal failure $(0.3 \%)$, Fanconi syndrome $(<0.1 \%)$, and increased serum creatinine $(<0.1 \%) .{ }^{114}$ For clinical practice, all TDF-treated patients should be checked for renal function at baseline and periodically thereafter. Consideration should also be given to monitoring serum phosphate. Other side effects of interest such as pancreatitis are rare, and similar incidences were reported compared to both patients with advanced HIV disease and patients treated with other antiretroviral agents. ${ }^{14,115}$ Small decreases in bone mineral density have been reported as well, but the clinical relevance is debated. ${ }^{116}$ In the phase III registration trials in HBV-monoinfected patients, TDF appeared to be safe and was well tolerated. The incidence and grade of adverse events was comparable to ADV. No increased in serum creatinine or creatinine clearance $<50 \mathrm{~mL} / \mathrm{min}$ among TDF-treated patients were observed. ${ }^{22,28}$

\section{Conclusion - place in therapy}

In the field of HIV management, TDF plays a pivotal role and has demonstrated to be a safe a well-tolerated antiviral agent. Recent data showed that the efficacy of the use of TDF in the treatment of chronically HBV-infected patients. TDF was superior to ADV in both nucleos(t)ide-naïve $\mathrm{HBeAg}$-positive and HBeAg-negative HBV patients, and appeared to be one of the most potent antiviral agents so far. In addition, several reports showed that TDF was also effective in the nucleos $(\mathrm{t})$ ide-experienced population, although conflicting results have been presented concerning patients with genotypic resistance to ADV. TDF seems to have a good resistance profile as well. The rtA194T mutation in association with LAM-resistance may confer resistance to TDF, although both in vivo and in vitro studies regarding this mutation demonstrate conflicting results. As treatment with TDF may be associated with nephrotoxicity, all TDF-treated patients should be checked for renal function at baseline and periodically thereafter. While the relative roles of interferon vs NA as initial anti-HBV therapy remains unclear, TDF will probably become one of the key factors in HBV management both as first-choice NA for nucleos(t)ide-naïve patients and as rescue therapy for nucleos $(\mathrm{t})$ ide-experienced patients.

TDF monotherapy appears to be sufficient in nucleos $(t)$ idenaïve patients. Whether an "add-on" strategy should also be applied to TDF as it is with ADV in case of development of resistance remains to be determined. Until now, resistance to TDF has not been observed, but follow-up is still very short, and all viremic HBV patients were switched to combination therapy in an early stage, thus not allowing for resistance to TDF monotherapy to develop. Studies investigating whether a sustained response after discontinuation of TDF monotherapy can be achieved are needed. However, it seems likely, as with the other NA, that long-term or even indefinite treatment is indicated for the majority of patients. In addition, as recently was stated by the National Institutes of Health, it should be stressed that there is a significant lack of conclusive evidence for anti-HBV therapy in general, but especially for NA, which demonstrates a beneficial effect on overall mortality, liver-specific mortality, or development of liver cirrhosis and hepatocellular carcinoma.

\section{Disclosures}

Prof. HLA Janssen has received grants from, and is consultant for, Bristol-Myers Squibb, Gilead, Novartis, Roche and Schering-Plough. JGP Reijnders has no disclosures.

\section{References}

1. de Franchis R HA, Lau G, Lavanchy D, Lok A, McIntyre N, Mele A, et al. EASL International Consensus Conference on Hepatitis B. 13-14 September, 2002 Geneva, Switzerland. Consensus statement (long version). J Hepatol. 2003;39 Suppl 1:S3-S25.

2. Kane M. Global programme for control of hepatitis B infection. Vaccine. 1995;13 Suppl 1:S47-S49.

3. Stevens CE, Beasley RP, Tsui J, Lee WC. Vertical transmission of hepatitis B antigen in Taiwan. N Engl J Med. 1975;292(15):771-774.

4. Tassopoulos NC, Papaevangelou GJ, Sjogren MH, RoumeliotouKarayannis A, Gerin JL, Purcell RH. Natural history of acute hepatitis B surface antigen-positive hepatitis in Greek adults. Gastroenterology. 1987;92(6):1844-1850.

5. Bortolotti F, Cadrobbi P, Crivellaro C, Guido M, Rugge M, Noventa F, et al. Long-term outcome of chronic type $\mathrm{B}$ hepatitis in patients who acquire hepatitis B virus infection in childhood. Gastroenterology. 1990;99(3):805-810. 
6. Fattovich G, Rugge M, Brollo L, Pontisso P, Noventa F, Guido M, et al. Clinical, virologic and histologic outcome following seroconversion from $\mathrm{HBeAg}$ to anti-HBe in chronic hepatitis type B. Hepatology. 1986;6(2):167-172.

7. Liaw YF, Chu CM, Su IJ, Huang MJ, Lin DY, Chang-Chien CS. Clinical and histological events preceding hepatitis $\mathrm{B}$ e antigen seroconversion in chronic type B hepatitis. Gastroenterology. 1983;84(2): 216-219.

8. Hsu YS, Chien RN, Yeh CT, Sheen IS, Chiou HY, Chu CM, et al. Longterm outcome after spontaneous $\mathrm{HBe} A g$ seroconversion in patients with chronic hepatitis B. Hepatology. 2002;35(6):1522-1527.

9. Manno M, Camma C, Schepis F, Bassi F, Gelmini R, Giannini F, et al. Natural history of chronic HBV carriers in northern Italy: morbidity and mortality after 30 years. Gastroenterology. 2004;127(3): 756-763.

10. Buckwold VE, Xu Z, Chen M, Yen TS, Ou JH. Effects of a naturally occurring mutation in the hepatitis $\mathrm{B}$ virus basal core promoter on precore gene expression and viral replication. J Virol. 1996;70(9): $5845-5851$.

11. Carman WF, Jacyna MR, Hadziyannis S, Karayiannis P, McGarvey MJ, Makris A, et al. Mutation preventing formation of hepatitis B e antigen in patients with chronic hepatitis B infection. Lancet. 1989;2(8663): 588-589.

12. Brunetto MR, Oliveri F, Coco B, Leandro G, Colombatto P, Gorin $\mathrm{JM}$, et al. Outcome of anti-HBe positive chronic hepatitis B in alphainterferon treated and untreated patients: a long term cohort study. J Hepatol. 2002;36(2):263-270.

13. Lok AS, McMahon BJ. Chronic hepatitis B. Hepatology. 2007 26;45(2):507-539.

14. Kim HC, Nam CM, Jee SH, Han KH, Oh DK, Suh I. Normal serum aminotransferase concentration and risk of mortality from liver diseases: prospective cohort study. BMJ. 2004;328(7446):983.

15. Lai M, Hyatt BJ, Nasser I, Curry M, Afdhal NH. The clinical significance of persistently normal ALT in chronic hepatitis B infection. J Hepatol. 2007;47(6):760-767.

16. Papatheodoridis GV, Chrysanthos N, Hadziyannis E, Cholongitas E, Manesis EK. Longitudinal changes in serum HBV DNA levels and predictors of progression during the natural course of $\mathrm{HBeAg-nega-}$ tive chronic hepatitis B virus infection. J Viral Hepat. 2008;15(6): 434-441.

17. Chen CJ, Yang HI, Su J, Jen CL, You SL, Lu SN, et al. Risk of hepatocellular carcinoma across a biological gradient of serum hepatitis $\mathrm{B}$ virus DNA level. JAMA. 2006;295(1):65-73.

18. Iloeje UH, Yang HI, Su J, Jen CL, You SL, Chen CJ. Predicting cirrhosis risk based on the level of circulating hepatitis B viral load. Gastroenterology. 2006;130(3):678-686.

19. Chang TT, Gish RG, de Man R, Gadano A, Sollano J, Chao YC, et al. A comparison of entecavir and lamivudine for $\mathrm{HBeAg}$-positive chronic hepatitis B. N Engl J Med. 2006;354(10):1001-1010.

20. Dienstag JL, Schiff ER, Wright TL, Perrillo RP, Hann HW, Goodman Z, et al. Lamivudine as initial treatment for chronic hepatitis B in the United States. N Engl J Med. 1999;341(17):1256-1263.

21. Hadziyannis SJ, Tassopoulos NC, Heathcote EJ, Chang TT, Kitis G, Rizzetto M, et al. Adefovir dipivoxil for the treatment of hepatitis B e antigen-negative chronic hepatitis B. $N$ Engl J Med. 2003;348(9): 800-807.

22. Heathcote EJ, Gane E, De Man R, Lee S, Flisiak R, Manns M, et al. A randomized, double-blind, comparison of tenofovir DF (TDF) versus adefovir dipivoxil (ADV) for the treatment of $\mathrm{HBeAg}$-positive chronic hepatitis B (CHB). Hepatology. 2007;46;S861 A.

23. Janssen HL, van Zonneveld M, Senturk H, Zeuzem S, Akarca US, Cakaloglu $\mathrm{Y}$, et al. Pegylated interferon alfa- $2 \mathrm{~b}$ alone or in combination with lamivudine for $\mathrm{HBeAg}$-positive chronic hepatitis $\mathrm{B}$ : a randomised trial. Lancet. 2005;365(9454):123-129.

24. Lai CL, Chien RN, Leung NW, Chang TT, Guan R, Tai DI, et al. A one-year trial of lamivudine for chronic hepatitis B. Asia Hepatitis Lamivudine Study Group. N Engl J Med. 1998 Jul 9;339(2):61-68.
25. Lai CL, Gane E, Liaw YF, Hsu CW, Thongsawat S, Wang Y, et al. Telbivudine versus lamivudine in patients with chronic hepatitis B. N Engl J Med. 2007;357(25):2576-2588.

26. Lai CL, Shouval D, Lok AS, Chang TT, Cheinquer H, Goodman Z, et al. Entecavir versus lamivudine for patients with $\mathrm{HBeAg}$-negative chronic hepatitis B. N Engl J Med. 2006;354(10):1011-1020.

27. Lau GK, Piratvisuth T, Luo KX, Marcellin P, Thongsawat S, Cooksley G, et al. Peginterferon Alfa-2a, lamivudine, and the combination for HBeAg-positive chronic hepatitis B. $N$ Engl J Med. 2005; 352(26):2682-2695.

28. Marcellin P, Buti M, Krastev Z, Germanidis G, Kaita K, Kotzev I, et al. A randomized, double-blind, comparison of tenofovir DF (TDF) versus adefovir dipivoxil (ADV) for the treatment of HBeAg-negative chronic hepatitis B (CHB). Hepatology. 2007;46; S290A-S291A.

29. Marcellin P, Chang TT, Lim SG, Tong MJ, Sievert W, Shiffman ML, et al. Adefovir dipivoxil for the treatment of hepatitis $\mathrm{B}$ e antigen-positive chronic hepatitis B. N Engl J Med. 2003;348(9):808-816.

30. Marcellin P, Lau GK, Bonino F, Farci P, Hadziyannis S, Jin R, et al. Peginterferon alfa- $2 \mathrm{a}$ alone, lamivudine alone, and the two in combination in patients with $\mathrm{HBeAg}$-negative chronic hepatitis B. $N$ Engl $J$ Med. 2004;351(12):1206-1217.

31. Sorrell MF, Belongia EA, Costa J, Gareen IF, Grem JL, Inadomi JM, et al. National Institutes of Health Consensus Development Conference Statement: Management of Hepatitis B. Ann Int Med. 2009;150(2): 104-110.

32. Peters M. Actions of cytokines on the immune response and viral interactions: an overview. Hepatology. 1996;23(4):909-916.

33. van Nunen AB, Hansen BE, Suh DJ, Lohr HF, Chemello L, Fontaine $\mathrm{H}$, et al. Durability of $\mathrm{HBeAg}$ seroconversion following antiviral therapy for chronic hepatitis B: relation to type of therapy and pretreatment serum hepatitis B virus DNA and alanine aminotransferase. Gut. 2003;52(3):420-424.

34. Cooksley WG, Piratvisuth T, Lee SD, Mahachai V, Chao YC, Tanwandee T, et al. Peginterferon alpha-2a (40 kDa): an advance in the treatment of hepatitis B e antigen-positive chronic hepatitis B. J Viral Hepat. 2003;10(4):298-305.

35. Niederau C, Heintges T, Lange S, Goldmann G, Niederau CM, Mohr L, et al. Long-term follow-up of HBeAg-positive patients treated with interferon alfa for chronic hepatitis B. $N$ Engl $J$ Med. 1996;334(22):1422-1427.

36. van Zonneveld M, Honkoop P, Hansen BE, Niesters HG, Murad SD, de Man RA, et al. Long-term follow-up of alpha-interferon treatment of patients with chronic hepatitis B. Hepatology. 2004;39(3): 804-810.

37. Buster EH, Hansen BE, Buti M, Delwaide J, Niederau C, Michielsen PP, et al. Peginterferon alpha- $2 \mathrm{~b}$ is safe and effective in $\mathrm{HBeAg}$-positive chronic hepatitis B patients with advanced fibrosis. Hepatology. 2007;46(2):388-394.

38. Zoulim F. New insight on hepatitis B virus persistence from the study of intrahepatic viral cccDNA. J Hepatol. 2005;42(3):302-308.

39. Zoulim F, Perrillo R. Hepatitis B: reflections on the current approach to antiviral therapy. J Hepatol. 2008;48 Suppl 1:S2-S19.

40. Werle-Lapostolle B, Bowden S, Locarnini S, Wursthorn K, Petersen J, Lau G, et al. Persistence of cccDNA during the natural history of chronic hepatitis B and decline during adefovir dipivoxil therapy. Gastroenterology. 2004;126(7):1750-1758.

41. Tsiang M, Gibbs CS. Analysis of hepatitis B virus dynamics and its impact on antiviral development. Methods Mol Med. 2004;96: 361-377.

42. Wursthorn K, Lutgehetmann M, Dandri M, Volz T, Buggisch P, Zollner B, et al. Peginterferon alpha-2b plus adefovir induce strong cccDNA decline and HBsAg reduction in patients with chronic hepatitis B. Hepatology. 2006;44(3):675-684.

43. Liaw YF, Sung JJ, Chow WC, Farrell G, Lee CZ, Yuen H, et al. Lamivudine for patients with chronic hepatitis B and advanced liver disease. $N$ Engl J Med. 2004 7;351(15):1521-1531. 
44. Nowak MA, Bonhoeffer S, Hill AM, Boehme R, Thomas HC, McDade H. Viral dynamics in hepatitis B virus infection. Proc Natl Acad Sci USA. 1996;93(9):4398-4402.

45. Locarnini S, Qi X, Arterburn S, Snow A, Brosgart C, Currie G, et al. Incidence and and predictors of emergence of adefovir resistant $\mathrm{HBV}$ during 4 years of adefovir dipivoxil (ADV) therapy for patients with chronic hepatitis B (CHB) (abstract). J Hepatol. 2005;42:17.

46. Yuen MF, Sablon E, Hui CK, Yuan HJ, Decraemer H, Lai CL. Factors associated with hepatitis B virus DNA breakthrough in patients receiving prolonged lamivudine therapy. Hepatology. 2001;34(4Pt 1): $785-791$.

47. Keeffe EB, Zeuzem S, Koff RS, Dieterich DT, Esteban-Mur R, Gane EJ, et al. Report of an international workshop: Roadmap for management of patients receiving oral therapy for chronic hepatitis B. Clin Gastroenterol Hepatol. 2007;5(8):890-897.

48. Delta: a randomised double-blind controlled trial comparing combinations of zidovudine plus didanosine or zalcitabine with zidovudine alone in HIV-infected individuals. Delta Coordinating Committee. Lancet. 1996;348(9023):283-291.

49. Balzarini J, Holy A, Jindrich J, Naesens L, Snoeck R, Schols D, et al. Differential antiherpesvirus and antiretrovirus effects of the (S) and (R) enantiomers of acyclic nucleoside phosphonates: potent and selective in vitro and in vivo antiretrovirus activities of (R)-9(2-phosphonomethoxypropyl)-2,6-diaminopurine. Antimicrob Agents Chemother. 1993;37(2):332-338.

50. Shaw JP, Sueoko CM, Oliyai R, Lee WA, Arimilli MN, Kim CU, et al. Metabolism and pharmacokinetics of novel oral prodrugs of 9-(R)-2(phosphonomethoxy)propyl. adenine (PMPA) in dogs. Pharm Res. 1997;14(12):1824-1829.

51. Delaney WEt, Ray AS, Yang H, Qi X, Xiong S, Zhu Y, et al. Intracellular metabolism and in vitro activity of tenofovir against hepatitis B virus. Antimicrob Agents Chemother. 2006;50(7):2471-2477.

52. van Gelder J, Deferme S, Naesens L, De Clercq E, van den Mooter G, Kinget R, et al. Intestinal absorption enhancement of the ester prodrug tenofovir disoproxil fumarate through modulation of the biochemical barrier by defined ester mixtures. Drug Metab Dispos. 2002;30(8): 924-930.

53. Robbins BL, Srinivas RV, Kim C, Bischofberger N, Fridland A. Anti-human immunodeficiency virus activity and cellular metabolism of a potential prodrug of the acyclic nucleoside phosphonate 9-R(2-phosphonomethoxypropyl)adenine (PMPA), Bis(isopropyloxymethy lcarbonyl)PMPA. Antimicrob Agents Chemother. 1998;42(3):612-617.

54. De Clercq E, Holy A. Acyclic nucleoside phosphonates: a key class of antiviral drugs. Nat Rev. 2005;4(11):928-940.

55. Kearney BP, Flaherty JF, Shah J. Tenofovir disoproxil fumarate: clinical pharmacology and pharmacokinetics. Clin Pharmacokinet. 2004;43(9):595-612.

56. Barditch-Crovo P, Deeks SG, Collier A, Safrin S, Coakley DF, Miller M, et al. Phase i/ii trial of the pharmacokinetics, safety, and antiretroviral activity of tenofovir disoproxil fumarate in human immunodeficiency virus-infected adults. Antimicrob Agents Chemother. 2001;45(10):2733-2739.

57. Hazra R, Balis FM, Tullio AN, DeCarlo E, Worrell CJ, Steinberg SM, et al. Single-dose and steady-state pharmacokinetics of tenofovir disoproxil fumarate in human immunodeficiency virus-infected children. Antimicrob Agents Chemother. 2004;48(1):124-129.

58. Bodsworth NJ, Cooper DA, Donovan B. The influence of human immunodeficiency virus type 1 infection on the development of the hepatitis B virus carrier state. J Infect Dis. 1991;163(5):1138-1140.

59. Konopnicki D, Mocroft A, de Wit S, Antunes F, Ledergerber B, Katlama C, et al. Hepatitis B and HIV: prevalence, AIDS progression, response to highly active antiretroviral therapy and increased mortality in the EuroSIDA cohort. AIDS. 2005;19(6):593-601.

60. Bani-Sadr F, Palmer P, Scieux C, Molina JM. Ninety-six-week efficacy of combination therapy with lamivudine and tenofovir in patients coinfected with HIV-1 and wild-type hepatitis B virus. Clin Infect Dis. 2004;39(7):1062-1064.
61. Benhamou Y, Fleury H, Trimoulet P, Pellegrin I, Urbinelli R, Katlama C, et al. Anti-hepatitis B virus efficacy of tenofovir disoproxil fumarate in HIV-infected patients. Hepatology. 2006;43(3):548-555.

62. de Vries-Sluijs TE, van der Eijk AA, Hansen BE, Osterhaus AD, de Man RA, van der Ende ME. Wild type and YMDD variant of hepatitis B virus: no difference in viral kinetics on lamivudine/tenofovir therapy in HIV-HBV co-infected patients. J Clin Virol. 2006;36(1): $60-63$.

63. Dore GJ, Cooper DA, Pozniak AL, DeJesus E, Zhong L, Miller MD, et al. Efficacy of tenofovir disoproxil fumarate in antiretroviral therapynaive and -experienced patients coinfected with HIV-1 and hepatitis B virus. J Infect Dis. 2004;189(7):1185-1192.

64. Gutierrez S, Guillemi S, Jahnke N, Montessori V, Harrigan PR, Montaner JS. Tenofovir-based rescue therapy for advanced liver disease in 6 patients coinfected with HIV and hepatitis B virus and receiving lamivudine. Clin Infect Dis. 2008;46(3):e28-e30.

65. Jain MK, Comanor L, White C, Kipnis P, Elkin C, Leung K, et al. Treatment of hepatitis B with lamivudine and tenofovir in HIV/HBVcoinfected patients: factors associated with response. $J$ Viral Hepat. 2007;14(3):176-182.

66. Lacombe K, Gozlan J, Boelle PY, Serfaty L, Zoulim F, Valleron AJ, et al. Long-term hepatitis B virus dynamics in HIV-hepatitis B virusco-infected patients treated with tenofovir disoproxil fumarate. AIDS. 2005;19(9):907-915.

67. Lacombe K, Gozlan J, Boyd A, Boelle PY, Bonnard P, Molina JM, et al. Comparison of the antiviral activity of adefovir and tenofovir on hepatitis B virus in HIV-HBV-coinfected patients. Antivir Ther. 2008;13(5):705-713.

68. Matthews GV, Avihingsanon A, Lewin SR, Amin J, Rerknimitr R, Petcharapirat $\mathrm{P}$, et al. A randomized trial of combination hepatitis $\mathrm{B}$ therapy in HIV/HBV coinfected antiretroviral naive individuals in Thailand. Hepatology. 2008;48(4):1062-1069.

69. Matthews GV, Cooper DA, Dore GJ. Improvements in parameters of end-stage liver disease in patients with HIV/HBV-related cirrhosis treated with tenofovir. Antivir Ther. 2007;12(1):119-122.

70. Nelson M, Portsmouth S, Stebbing J, Atkins M, Barr A, Matthews G, et al. An open-label study of tenofovir in HIV-1 and Hepatitis B virus co-infected individuals. AIDS. 2003;17(1):F7-F10.

71. Nunez M, Perez-Olmeda M, Diaz B, Rios P, Gonzalez-Lahoz J, Soriano V. Activity of tenofovir on hepatitis B virus replication in HIV-co-infected patients failing or partially responding to lamivudine. AIDS. 2002;16(17):2352-2354.

72. Peters MG, Andersen J, Lynch P, Liu T, Alston-Smith B, Brosgart CL, et al. Randomized controlled study of tenofovir and adefovir in chronic hepatitis B virus and HIV infection: ACTG A5127. Hepatology. 2006;44(5):1110-1116.

73. Quiros-Roldan E, Calabresi A, Lapadula G, Tirelli V, Costarelli S, Cologni G, et al. Evidence of long-term suppression of hepatitis B virus DNA by tenofovir as rescue treatment in patients coinfected by HIV. Antivir Ther. 2008;13(3):341-348.

74. Ristig MB, Crippin J, Aberg JA, Powderly WG, Lisker-Melman M, Kessels L, et al. Tenofovir disoproxil fumarate therapy for chronic hepatitis B in human immunodeficiency virus/hepatitis B viruscoinfected individuals for whom interferon-alpha and lamivudine therapy have failed. $J$ Infect Dis. 2002;186(12):1844-1847.

75. Schmutz G, Nelson M, Lutz T, Sheldon J, Bruno R, von Boemmel F, et al. Combination of tenofovir and lamivudine versus tenofovir after lamivudine failure for therapy of hepatitis B in HIV-coinfection. AIDS. 2006;20(15):1951-1954.

76. Stephan C, Berger A, Carlebach A, Lutz T, Bickel M, Klauke S, et al. Impact of tenofovir-containing antiretroviral therapy on chronic hepatitis B in a cohort co-infected with human immunodeficiency virus. $J$ Antimicrob Chemother. 2005;56(6):1087-1093.

77. van Bommel F, Wunsche T, Mauss S, Reinke P, Bergk A, Schurmann D, et al. Comparison of adefovir and tenofovir in the treatment of lamivudine-resistant hepatitis B virus infection. Hepatology. 2004; 40(6):1421-1425. 
78. van der Eijk AA, Hansen BE, Niesters HG, Janssen HL, van de Ende M, Schalm SW, et al. Viral dynamics during tenofovir therapy in patients infected with lamivudine-resistant hepatitis B virus mutants. $J$ Viral Hepat. 2005; 12(4):364-372.

79. Heathcote EJ, Gane E, De Man R, Chan S, Sievert W, Mauss S, et al. Two year tenofovir disoproxil fumarate (TDF) treatment and adefovir dipivoxil (ADV) switch data in $\mathrm{HBeAg}$-positive patients with chronic hepatitis B (study 103), preliminary analysis. Hepatology. 2008;48 Suppl 1:A158.

80. Heathcote EJ, George J, Gordon SC, Bronowicki JP, Sperl J, Williams R, et al. Tenofovir disoproxil fumarate (TDF) for the treatment of HBeAg-positive chronic hepatitis B: week 72 TDF data and week 24 adefovir dipivoxil switch data (study 103). J Hepatol. 2008;48 Suppl 2:A72.

81. Marcellin P, Buti M, Krastev Z, Gurel S, Balabanska R, Dusheiko G, et al. Two year tenofovir disoproxil fumarate (TDF) treatment and adefovir dipivoxil (ADV) switch data in HBeAg-negative patients with chronic hepatitis B (study 102), preliminary analysis. Hepatology. 2008; 48 Suppl 1:A146.

82. Marcellin P, Jacobson IM, Habersetzer F, Senturk H, Andreone P, Moyes $\mathrm{C}$, et al. Tenofovir disoproxil fumarate (TDF) for the treatment of HBeAg-negative chronic hepatitis B: week 72 and week 24 adefovir dipivoxil switch data (study 102). J Hepatol. 2008;48 Suppl 2:A57.

83. Lai CL, Dienstag J, Schiff E, Leung NW, Atkins M, Hunt C, et al. Prevalence and clinical correlates of YMDD variants during lamivudine therapy for patients with chronic hepatitis B. Clin Infect Dis. 2003;36(6):687-696.

84. Van Bommel F, De Man R, Erhardt A, Huppe D, Stein K, Buggisch P, et al. First multicenter evaluation of the efficacy of tenofovir in nucleos $(\mathrm{t})$ ide analog experienced patients with HBV monoinfection. Hepatology. 2007;46:S270A.

85. Manns M, Jeffers L, Dalekos G, Berg T, Trepo C, Roberts S, et al. The antiviral response to tenofovir disoproxil fumarate (TDF) is comparable in lamivudine (LAM)-naive and LAM-experienced subjects treated for chronic hepatitis B (CHB). J Hepatol. 2008;48 Suppl 2:A74.

86. Leemans WF, Janssen HL, Niesters HG, de Man RA. Switching patients with lamivudine resistant chronic hepatitis B virus from tenofovir to adefovir results in less potent HBV-DNA suppression. $J$ Viral Hepat. 2008;15(2):108-114.

87. Schildgen O, Hartmann H, Gerlich WH. Replacement of tenofovir with adefovir may result in reactivation of hepatitis B virus replication. Scand J Gastroenterol. 2006;41(2):245-246.

88. van Bommel F, Berg T. Reactivation of viral replication after replacement of tenofovir by adefovir. Hepatology. 2005;42(1):239-240.

89. van Bommel F, Zollner B, Sarrazin C, Spengler U, Huppe D, Moller B, et al. Tenofovir for patients with lamivudine-resistant hepatitis $B$ virus (HBV) infection and high HBV DNA level during adefovir therapy. Hepatology. 2006;44(2):318-325.

90. Van Bommel F, De Man R, Stein K, Huppe D, Petersen J, Buggisch P, et al. A multicenter analysis of antiviral response after one year of tenofovir monotherapy in $\mathrm{HBV}$-monoinfected patients with prior nucleos(t)ide analog experience. $J$ Hepatol. 2008;48 Suppl 2:A73

91. Van Bommel F, Trojan J, Feucht H, Moller B, Huppe D, Wiedenmann B, et al. Tenofovir shows limited efficay in treatment of HBV infections resistant against adefovir. Hepatology. 2007;46:S664A

92. Tan J, Degertekin B, Wong SN, Husain M, Oberhelman K, Lok AS Tenofovir monotherapy is effective in hepatitis B patients with antiviral treatment failure to adefovir in the absence of adefovir-resistant mutations. J Hepatol. 2008;48(3):391-398.

93. Villet S, Pichoud C, Villeneuve JP, Trepo C, Zoulim F. Selection of a multiple drug-resistant hepatitis B virus strain in a liver-transplanted patient. Gastroenterology. 2006;131(4):1253-1261.

94. Berg T, Moller B, Trinh H, Chan S, Marcellin P, Suarez E, et al. Tenofovir disoproxil fumarate (TDF) versus emtricitabine plus TDF for treatment of chronic hepatitis B (CHB) in subjects with persistent viral replication in receiving adefovir dipivoxil (ADV). J Hepatol. 2008; 48 Suppl 2:A76.
95. Sherman M, Yurdaydin C, Sollano J, Silva M, Liaw YF, Cianciara J, et al. Entecavir for treatment of lamivudine-refractory, HBeAg-positive chronic hepatitis B. Gastroenterology. 2006;130(7):2039-2049.

96. Leemans WF, Niesters HG, van der Eijk AA, Janssen HL, Schalm SW, de Man RA. Selection of an entecavir-resistant mutant despite prolonged hepatitis B virus DNA suppression, in a chronic hepatitis B patient with preexistent lamivudine resistance: successful rescue therapy with tenofovir. Eur J Gastroenterol Hepatol. 2008;20(8): 773-777.

97. Pan C, Hu K. Excellent treatment response to tenofovir (TDF) monotherapy in chronic hepatitis $\mathrm{B}$ (CHB) patients with prior suboptimal response to entecavir (ETV) monotherapy. Hepatology. 2008; 48 Suppl 1:A932.

98. Buti M, Hadziyannis S, Mathurin P, Urbanek P, Sherman M, Strasser S, et al. Tenofovir disoproxil fumarate (TDF) is highly active for treatment of chronic hepatitis B in subjects with cirrhosis. $J$ Hepatol. 2008;48 Supp1 2:A75.

99. Sheldon J, Camino N, Rodes B, Bartholomeusz A, Kuiper M, Tacke F, et al. Selection of hepatitis B virus polymerase mutations in HIVcoinfected patients treated with tenofovir. Antivir Ther. 2005;10(6): 727-734.

100. Fung SK, Mazzulli T, Sherman M, Popovic V, Sablon E. Presence of rtA194T mutation at baseline does not reduce efficacy to tenofovir (TDF) in patients iwth lamivudine(LAM)-resistant chronic hepatitis B. Hepatology. 2008;48 Suppl 1:A880.

101. Amini-Bavil-Olyaee S, Sheldon J, Trautwein C, Tacke F. Precore and basal core promotor mutation restore the reduced replication efficacy of tenofovir-resistance associated rtA194T polymerase mutations of the hepatitis B virus. Hepatology. 2008; 48 Suppl 1:A842.

102. Brunelle MN, Jacquard AC, Pichoud C, Durantel D, CarroueeDurantel S, Villeneuve JP, et al. Susceptibility to antivirals of a human HBV strain with mutations conferring resistance to both lamivudine and adefovir. Hepatology. 2005;41(6):1391-1398.

103. Brunelle MN, Lucifora J, Neyts J, Villet S, Holy A, Trepo C, et al. In vitro activity of 2,4-diamino-6-[2-(phosphonomethoxy)ethoxy]pyrimidine against multidrug-resistant hepatitis B virus mutants. Antimicrob Agents Chemother. 2007;51(6):2240-2243.

104. Qi X, Xiong S, Yang H, Miller M, Delaney WEt. In vitro susceptibility of adefovir-associated hepatitis B virus polymerase mutations to other antiviral agents. Antivir Ther. 2007;12(3):355-362.

105. Villet S, Pichoud C, Billioud G, Barraud L, Durantel S, Trepo C, et al. Impact of hepatitis B virus rtA181V/T mutants on hepatitis B treatment failure. J Hepatol. 2008;48(5):747-755.

106. Snow A, Chappell B, Curtis M, Zhu Y, Heathcote EJ, Marcellin P, et al. Week 96 resistance surveillance for $\mathrm{HBeAg}$-positive and negative subjects with chronic HBV infection randomized to receive tenofovir DF 300 mg QD. Hepatology. 2008;48; suppl 1: A977.

107. Snow A, Sorbel J, Chappell B, Curtis M, Zhu Y, Borroto-Esoda K Lack of tenofovir DF (TDF) resistance mutations in treatmentnaive and treatment-experienced subjects with chronic HBV infection following 48 weeks of TDF monotherapy. EASL conference Hepatitis $B$ and $C$ virus: resistance to antiviral therapy. Paris, France 2008.

108. Vigano M, Lampertico P, Iavarone M, Tontini G, Facchetti F, Colombo M. High risk of renal impairment and arterial hypertension during long-term adefovir and lamivudine combination therapy in patients with lamivudine-resistant chronic hepatitis B. Hepatology. 2008;48 Suppl 1:A897.

109. Coca S, Perazella MA. Rapid communication: acute renal failure associated with tenofovir: evidence of drug-induced nephrotoxicity. Am J Med Sci. 2002;324(6):342-344.

110. Karras A, Lafaurie M, Furco A, Bourgarit A, Droz D, Sereni D, et al. Tenofovir-related nephrotoxicity in human immunodeficiency virusinfected patients: three cases of renal failure, Fanconi syndrome, and nephrogenic diabetes insipidus. Clin Infect Dis. 2003;36(8): 1070-1073. 
111. Rollot F, Nazal EM, Chauvelot-Moachon L, Kelaidi C, Daniel N, Saba M, et al. Tenofovir-related Fanconi syndrome with nephrogenic diabetes insipidus in a patient with acquired immunodeficiency syndrome: the role of lopinavir-ritonavir-didanosine. Clin Infect Dis. 2003;37(12):e174-e176.

112. Gallant JE, Parish MA, Keruly JC, Moore RD. Changes in renal function associated with tenofovir disoproxil fumarate treatment, compared with nucleoside reverse-transcriptase inhibitor treatment. Clin Infect Dis. 2005;40(8):1194-1198.

113. Jones R, Stebbing J, Nelson M, Moyle G, Bower M, Mandalia S, et al. Renal dysfunction with tenofovir disoproxil fumarate-containing highly active antiretroviral therapy regimens is not observed more frequently: a cohort and case-control study. J Acquir Immune Defic Syndr. 2004;37(4):1489-1495.
114. Nelson MR, Katlama C, Montaner JS, Cooper DA, Gazzard B, Clotet B, et al. The safety of tenofovir disoproxil fumarate for the treatment of HIV infection in adults: the first 4 years. AIDS. 2007;21(10):1273-1281.

115. Reisler RB, Murphy RL, Redfield RR, Parker RA. Incidence of pancreatitis in HIV-1-infected individuals enrolled in 20 adult AIDS clinical trials group studies: lessons learned. J Acquir Immune Defic Syndr. 2005;39(2):159-166.

116. Gallant JE, Staszewski S, Pozniak AL, DeJesus E, Suleiman JM, Miller MD, et al. Efficacy and safety of tenofovir DF vs stavudine in combination therapy in antiretroviral-naive patients: a 3-year randomized trial. JAMA. 2004;292(2):191-201. 